44. Bonilla MA, Gillio AP, Ruggeiro M, Kernan NA, Brochstein JA, Abboud M, Fumagalli L, Vincent M, Gabrilove JL, Welte K, Souza LM, O'Reilly RJ 1989 Effects of recombinant human granulocyte colony-stimulating factor on neutropenia in patients with congenital agranulocytosis. $\mathrm{N}$ Engl $\mathrm{J}$ Med 320:1574-1580

45. Weston B, Todd RF III, Axtell R, Balazovich K, Stewart J, Locey BJ, MayoBond L, Loos P, Hutchinson R, Boxer LA 1991 Severe congenital neutropenia: clinical effects and neutrophil function during treatment with granulocyte colony stimulating factor. J Lab Clin Med 117:282-290

46. Monroy RL, Davis TA, MacVittie TJ 1990 Granulocyte-macrophage colony stimulating factor: more than a hemopoietin. Clin Immunol Immunopathol 54:333-346

47. Elsner J, Kaever V, Emmendörffer A, Breidenbach T, Lohmann-Matthes M-L, Roesler J 1992 Heterogeneity in the mobilization of cytoplasmic calcium by human polymorphonuclear leukocytes in response to AMP, C5a and IL-8/NAP-1. J Leukocyte Biol 51:77-83

48. Kuijpers TW, Hoogerwerf M, Roos D 1992 Neutrophil migration across monolayers of resting or cytokine-activated endothelial cells. Role of intracellular calcium changes and fusion of specific granules with the plasma membrane. J Immunol 148:72-77

\title{
Announcement
}

\section{Annual Meetings}

The American Pediatric Society, The Society for Pediatric Research, and The Ambulatory Pediatric Association will hold their annual meetings May 2-5, 1994 at the Washington State Convention and Trade Center, Seattle. For Further information, contact APS/SPR Association Headquarters, 141 Northwest Point Blvd., P.O. Box 675, Elk Grove Village, IL 60009-0675, phone (708) 427-0205, fax (708) 427-1305 or Ambulatory Pediatric Association, 6728 Old McLean Village, McLean, VA 22101, phone (703) 556-9222, fax (703) 556-8729. 